\title{
Physciochemical variations in the honey produced by Apis dorsata from Punjab, Pakistan
}

\author{
Rizwana Kousar ${ }^{1}$ and Samina Qamer ${ }^{2 *}$ \\ 1. Department of Zoology, Government College University, Faisalabad-Pakistan \\ 2. Honey Bee Research Institute, National Agricultural Research Centre, Islamabad-Pakistan \\ *Corresponding author's email: saminabee@yahoo.com \\ Citation \\ Rizwana Kousar and Samina Qamer. Physciochemical variations in the honey produced by Apis dorsata from \\ Punjab, Pakistan. Pure and Applied Biology. Vol. 6, Issue 2, pp733-739. \\ http://dx.doi.org/10.19045/bspab.2017.60078
}

Received: 27/10/2016

Revised: 09/03/2017

Accepted: 15/03/2017

Online First: 19/03/2017

\section{Abstract}

A total of 24 samples was collected from three different localities $(n=3$, Lahore, $n=10$, Jhang and $\mathrm{n}=11$, Kalar Kahar). These honey samples were analyzed for moisture content, $\mathrm{pH}$, electrical conductivity, free acidity, lactone content, total acidity, proline and HMF content for quality evaluation of Apis dorsata honey. The average moisture content was $22.86 \%, 22.97 \%$ and $21.13 \%$ from Lahore, Jhang and Kalar Kahar, respectively. The $\mathrm{pH}$ values fell within the prescribed range of 3.42-6.1. The mean free acidity of all honey samples was well with international limits. Lactone content was $33.44 \mathrm{meq} / \mathrm{kg}$ from Lahore, $15.53 \mathrm{meq} / \mathrm{kg}$ from Jhang and $12.77 \mathrm{meq} / \mathrm{kg}$ from Kalar Kahar. Total acidity calculated for honey samples of Lahore was $60.21 \mathrm{meq} / \mathrm{kg}, 55.46 \mathrm{meq} / \mathrm{kg}$ for Jhang and $50.36 \mathrm{meq} / \mathrm{kg}$ for Kalar Kahar region. Proline content was estimated at an average of $5146.62 \mathrm{mg} / \mathrm{kg}$ of honey samples from Lahore, $4328.44 \mathrm{mg} / \mathrm{kg}$ from Jhang and $3554.68 \mathrm{mg} / \mathrm{kg}$ from Kalar Kahar honey samples which were higher than minimum International Honey Standards limit. HMF content was measured as $36.41 \mathrm{mg} / \mathrm{kg}$ from Lahore, $30.44 \mathrm{mg} / \mathrm{kg}$ from Jhang and $89.93 \mathrm{mg} / \mathrm{kg}$ from Kalar Kahar. The HMF Content was within the maximum International limit.

Keywords: A.dorsata honey; Proline and HMF content; EC value

\section{Introduction}

Apis dorsata, the giant honeybee, is found in the tropical regions of Asia [1]. It is also one of the native honeybee species of Pakistan commonly known as "dommna" and wild in nature. It's yellow in color with black stripes on each adnominal segment. It usually builds a single comb which is 1-1.6 m wide and $0.8-1.5 \mathrm{~m}$ long under the stout branchs of tall trees or buildings or water tower or cliff to protect their nests from top predators [2]. The comb is formed by several layers of protective curtains of bees. These protective curtains keep a constant temperature for brood nest between 0-33 ${ }^{\circ} \mathrm{C}$. Apis dorsata seasonally migrates back and forth between low $(10 \mathrm{~m})$ and uplands $(1100 \mathrm{~m})$ to escape from harsh environmental conditions. When it migrates from low agriculture lands, they always aggregate in masses from 25-120 colonies (depend on nesting space availability). At this time of the year different types of honey crops are bloom. A single fully-grown nest may weigh over 20 
$\mathrm{kg}$ including brood, honey, pollen and adult bee. However, in wet season they never aggregate in masses probably due to scarcity of food, strong wind, heavy rain fall, storms, and the low number of individuals in the colony [3]. Although, physical properties and chemical composition of honey has been investigated by many workers $[4,5]$. However, it may vary with the bee species responsible for its production. In Pakistan commercial beekeeping is done by keeping A.mellifera (European honeybee species) hives and quality evaluation of honey in the country is mostly carried out by either buying or collecting honey available in local market or from beekeepers [6, 7]. The composition of honey also depends on the type of plant source utilized by the bees as well as regional and climatic conditions $[4$, 8, 9]. Honey is generally evaluated by a physicochemical analysis of constituents. Several of these constituents are of great importance to the honey industry as they influence the storage quality, granulation, texture, flavor and the nutritional and medicinal quality of the honey. The present study was aimed firstly to find Apis dorsata colonies on different floral sources and secondly to assess the physicochemical properties of Apis dorsata honey from Pakistan in order to increases the scientific knowledge about the honey produced by this honey bee species. A total of 24 samples were collected from three different localities
Nankan Sahib, Faisalabad and Kalar Kahar. The predominant vegetation in these areas were Guava, Jaman Eucalyptus in Nankana Sahib, Citrus, Phulai, Mulberry, Neem, Guava, Eucalyptus, Peepal, Acacia in Faisalabad and Jojoba, Phulai, Neem, Mulberry, Citrus, Mango, Acacia, Sheesham in Kalar Kahar.

\section{Materials and methods}

Fresh Pakistani Apis dorsata honey samples were collected from different areas of Punjab, Pakistan: Lahore (Figure 1), Jhang (Figure 2) and Kalar Kahar (Figure 3) (Table 1). All these samples, after collecting, were stored in tightly caped jars under ordinary room temperature $\left(25^{\circ} \mathrm{C}\right.$ $29^{\circ} \mathrm{C}$ ) in the laboratory until completely analysis. There was no sign of granulation in honey samples. No preservative or any heating was applied at any stage. Honey samples were diluted in distilled water at room temperature according to the requirements of the test. All tests were performed in triplicate at the Research laboratory of Zoology department of GC University, Faisalabad. The physicochemical methods used for the characterization of honey are those as recommended by International Honey Commission [10]. The data was subjected to statistical analysis in which different physicochemical parameters were compared with international reference limits using student's " $t$ " test [11].

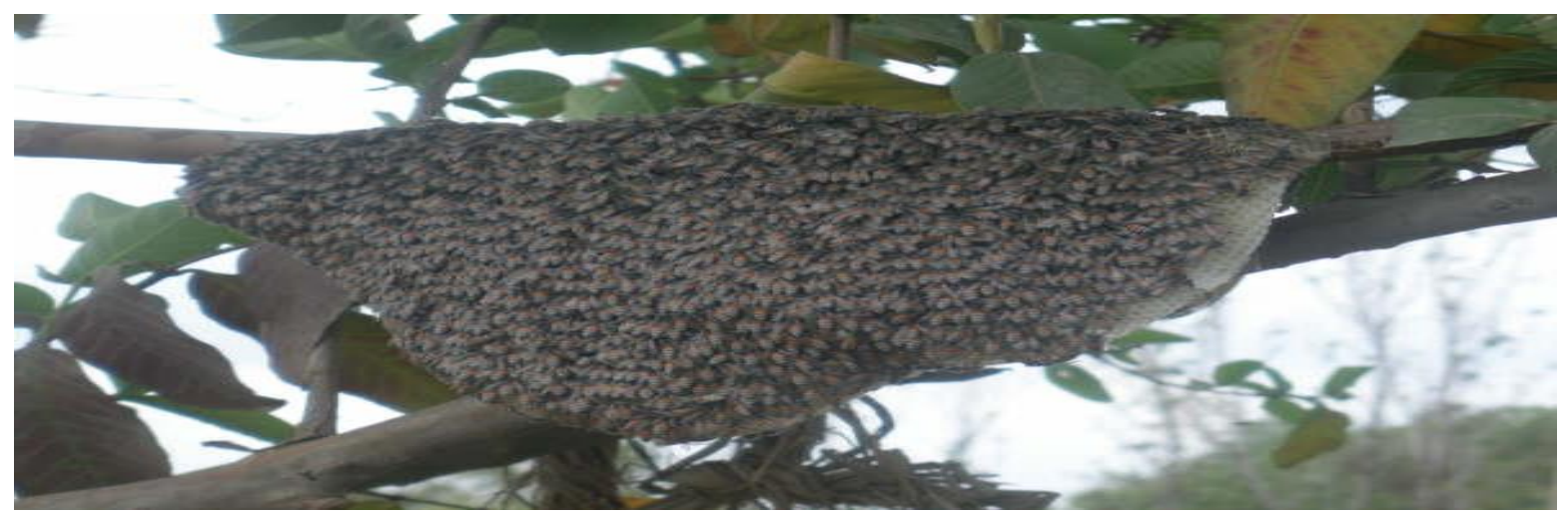

Figure 1. Colony of Apis dorsata on guava tree in Lahore 


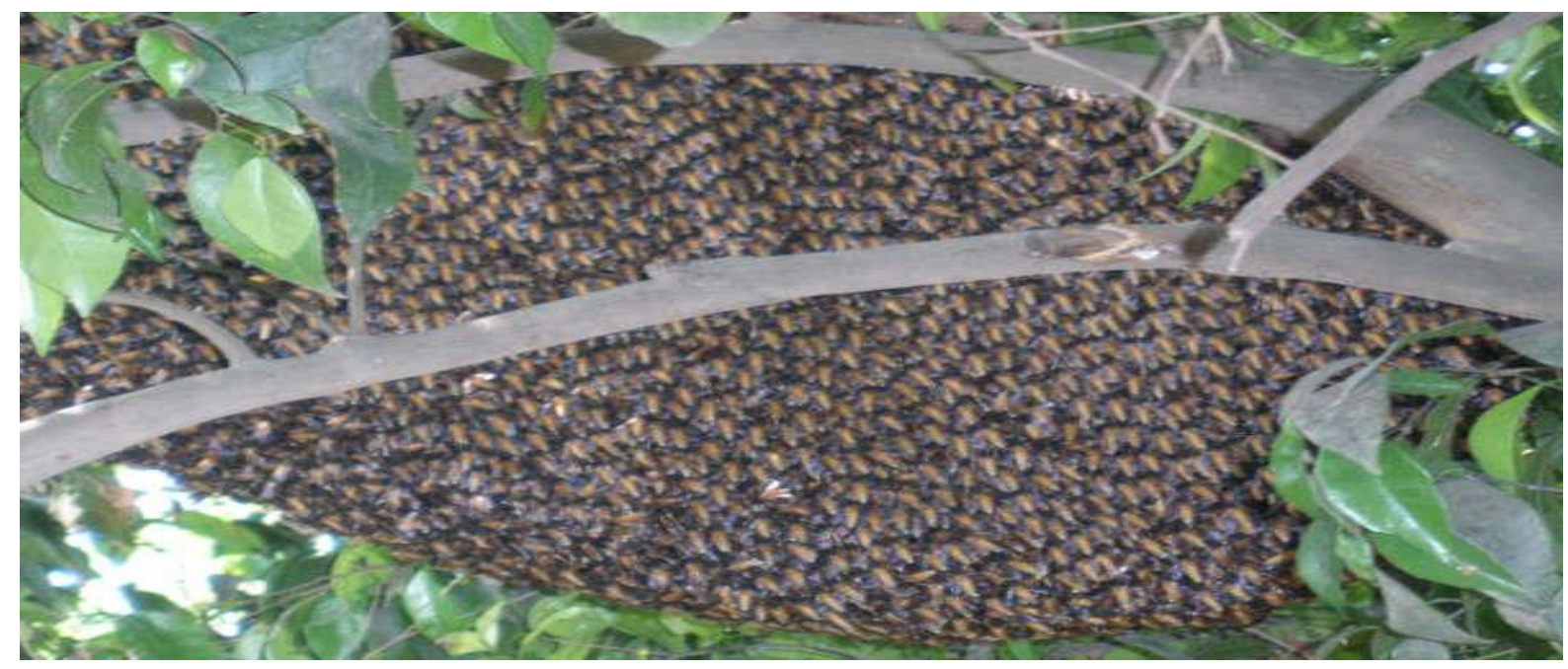

Figure 2. Colony of Apis dorsata on citrus tree in Jhang

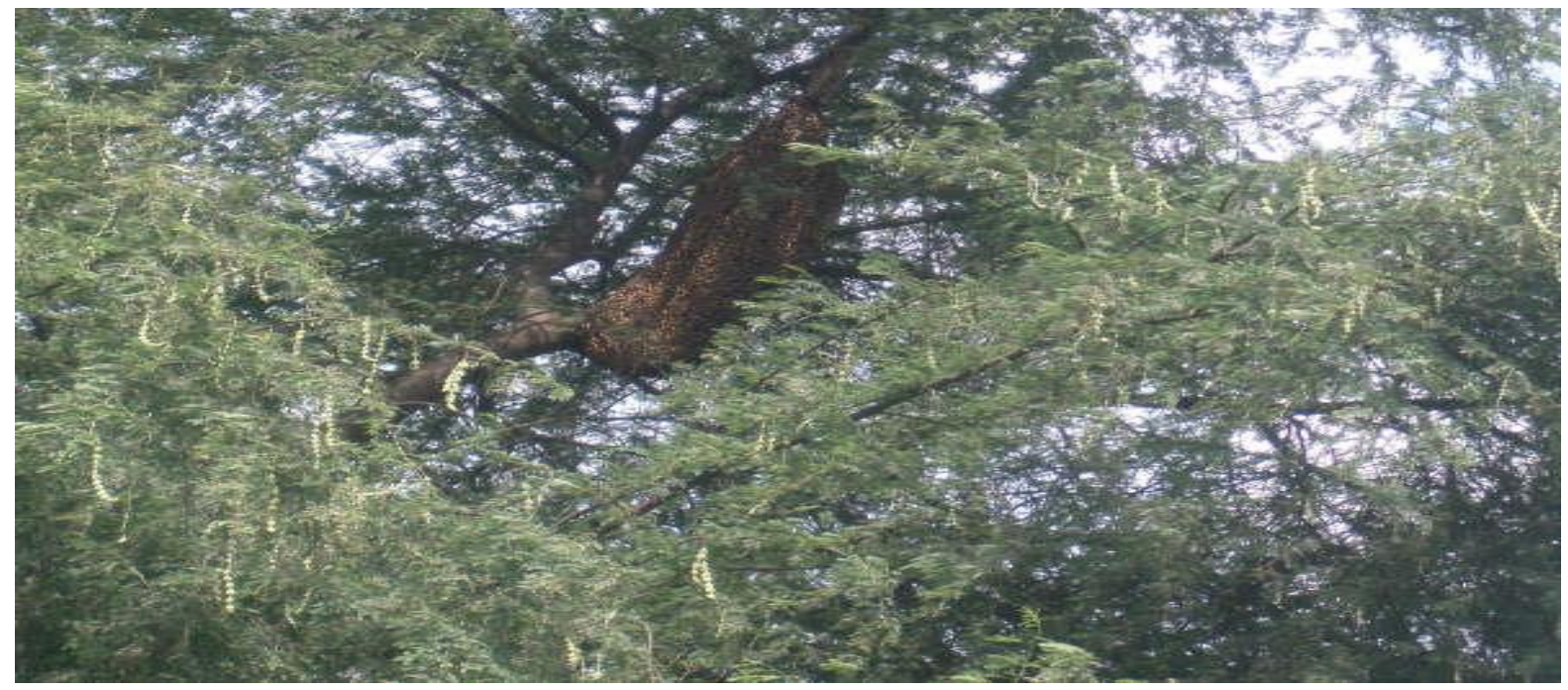

Figure 3. Colony of Apis dorsata on Acacia tree in Kalar Kahar

Table 1. Samples collection sites of Apis dorsata honey

\begin{tabular}{|c|c|c|c|}
\hline S.No & Nectar source (predominant) & Locality & No. of samples \\
\hline 1 & Guava, Jaman Eucalyptus & Lahore & 3 \\
\hline 2 & $\begin{array}{l}\text { Citrus, Phulai, Mulberry, Neem, Guava, Eucalyptus, } \\
\text { Peepal, Acacia }\end{array}$ & Jhang & 10 \\
\hline 3 & $\begin{array}{l}\text { Jojoba, Phulai, Neem, Mulberry, Citrus, Mango, } \\
\text { Acacia, Sheesham }\end{array}$ & Kalar Kahar & 11 \\
\hline
\end{tabular}

\section{Results and discussion} Moisture Content

The moisture content in all samples of Apis dorsata are exceeding (Table 2) the limits of International Honey Standards and of
Directive, 2001/110/EC from council of European Union, according to which water content of honey should not be more than 21\%. This higher moisture content in Apis dorsata honey has also been recoded 
previously by [12] from four $(23.5 \%$, $23.99 \%, 23.91 \%$ and $22.2 \%)$ different forests of Nepal, $20.9 \%$ (18.9-24.2) by [13], $21 \%$ by [14], $23.1 \%$ and $27.8 \%$ by [15] and [16] from Philippines. This high water content in Apis dorsata honey could be because of the possible dilution of honey by rain water as this honey bee species forms comb high in open air [17]. Therefore, uniformly high moisture content seems to be the peculiarity of Apis dorsata honey and could be used to evaluate the honey on the basis on honey bee species.

Table 2. Comparison of physico-chemical characteristics of Apis dorsata honey from Lahore, Jhang and Kalar Kahar

\begin{tabular}{|c|c|c|c|c|c|c|c|c|c|c|}
\hline \multirow[t]{2}{*}{ S. No } & \multirow{2}{*}{$\begin{array}{l}\text { Nesting site } \\
\rightarrow \\
\text { Parameters } \downarrow\end{array}$} & \multicolumn{2}{|l|}{ Jhang } & \multicolumn{2}{|l|}{ Lahore } & \multicolumn{2}{|c|}{ Kalar Kahar } & \multirow[t]{2}{*}{$\begin{array}{l}\text { Codex draft } \\
1999\end{array}$} & \multirow[t]{2}{*}{$\begin{array}{l}\text { EU draft } \\
1999\end{array}$} & \multirow[t]{2}{*}{$\begin{array}{l}\text { Directive } \\
\text { 2001/EC } \\
* *\end{array}$} \\
\hline & & Range & Mean & Range & Mean & Range & Mean & & & \\
\hline 1 & pH & $\begin{array}{l}3.57- \\
4.62\end{array}$ & $\begin{array}{l}4.11 \\
\pm 0.14\end{array}$ & $\begin{array}{l}3.44- \\
3.73 \\
\end{array}$ & $\begin{array}{l}3.48 \\
\pm 0.06\end{array}$ & $\begin{array}{l}3.52- \\
4.74 \\
\end{array}$ & $\begin{array}{l}4.62 \\
\pm 0.26\end{array}$ & & & \\
\hline 2 & $\begin{array}{l}\text { Moisture } \\
\text { content \% }\end{array}$ & $\begin{array}{l}22.20- \\
25.00\end{array}$ & $\begin{array}{l}22.97 \\
\pm 0.26 \\
\end{array}$ & $\begin{array}{l}21.80- \\
25.00 \\
\end{array}$ & $\begin{array}{l}22.86 \\
\pm 0.26 \\
\end{array}$ & $\begin{array}{l}21.67- \\
25.00\end{array}$ & $\begin{array}{l}21.13 \\
\pm 0.87 \\
\end{array}$ & $<21 \%$ & $<21 \%$ & $<21 \%$ \\
\hline 3 & $\begin{array}{l}\text { EC } \\
(\mu \mathrm{S} / \mathrm{cm})\end{array}$ & $\begin{array}{l}277.67- \\
1347.87 \\
\end{array}$ & $\begin{array}{l}911.534 \\
\pm 7.23 \\
\end{array}$ & $\begin{array}{l}233.00- \\
272.67\end{array}$ & $\begin{array}{l}249 \\
\pm 1.12 \\
\end{array}$ & $\begin{array}{l}258.67- \\
524.33\end{array}$ & $\begin{array}{l}459.97 \\
\pm 3.84\end{array}$ & $0.80 * \mathrm{mS} / \mathrm{cm}$ & & \\
\hline 4 & $\begin{array}{l}\text { Free acidity } \\
\text { (meq/kg) }\end{array}$ & $\begin{array}{l}21.67- \\
58.00\end{array}$ & $\begin{array}{l}42.64 \\
\pm 3.85 \\
\end{array}$ & $\begin{array}{l}19.00- \\
33.33 \\
\end{array}$ & $\begin{array}{l}25.77 \\
\pm 1.48 \\
\end{array}$ & $\begin{array}{l}26.83- \\
58.17 \\
\end{array}$ & $\begin{array}{l}37.11 \\
\pm 2.44 \\
\end{array}$ & $\leq 50 \mathrm{meq} / \mathrm{kg}$ & $\leq 40 \mathrm{meq} / \mathrm{kg}$ & $\leq 50 \mathrm{meq} / \mathrm{kg}$ \\
\hline 5 & $\begin{array}{l}\text { Lactone } \\
\text { content } \\
\text { (meq/kg) }\end{array}$ & $\begin{array}{l}4.00- \\
34.16\end{array}$ & $\begin{array}{l}15.53 \\
\pm 1.62\end{array}$ & $\begin{array}{l}30.00- \\
31.83\end{array}$ & $\begin{array}{l}33.44 \\
\pm 2.46\end{array}$ & $\begin{array}{l}6.00- \\
21.27\end{array}$ & $\begin{array}{l}12.77 \\
\pm 1.69\end{array}$ & & & \\
\hline 6 & $\begin{array}{l}\text { Total acidity } \\
(\mathrm{meq} / \mathrm{kg})\end{array}$ & $\begin{array}{l}51.20- \\
82.47 \\
\end{array}$ & $\begin{array}{l}55.46 \\
\pm 5.21 \\
\end{array}$ & $\begin{array}{l}51.20- \\
69.67 \\
\end{array}$ & $\begin{array}{l}60.21 \\
\pm 7.55 \\
\end{array}$ & $\begin{array}{l}31.67- \\
74.83 \\
\end{array}$ & $\begin{array}{l}50.36 \\
\pm 3.93 \\
\end{array}$ & & & \\
\hline 7 & $\begin{array}{l}\text { Proline } \\
\text { content } \\
(\mathrm{mg} / \mathrm{kg})\end{array}$ & $\begin{array}{l}3415.73- \\
6344.61\end{array}$ & $\begin{array}{l}4328.44 \\
\pm 342.67\end{array}$ & $\begin{array}{l}4465.13- \\
8760.51\end{array}$ & $\begin{array}{l}5146.62 \\
\pm 2.46\end{array}$ & $\begin{array}{l}2808.38- \\
7939.09\end{array}$ & $\begin{array}{l}3554.68 \\
\pm 359.81\end{array}$ & $\geq 180 * \mathrm{mg} / \mathrm{kg}$ & & \\
\hline 8 & $\begin{array}{l}\text { HMF content } \\
(\mathrm{mg} / \mathrm{kg})\end{array}$ & $\begin{array}{l}14.82- \\
43.76\end{array}$ & $\begin{array}{l}30.44 \\
\pm 5.29\end{array}$ & $\begin{array}{l}28.54- \\
43.33\end{array}$ & $\begin{array}{l}36.41 \\
\pm 4.46\end{array}$ & $\begin{array}{l}48.54- \\
149.76\end{array}$ & $\begin{array}{l}89.93 \\
\pm 5.40\end{array}$ & $\leq 60 \mathrm{mg} / \mathrm{kg}$ & & \\
\hline
\end{tabular}

“t”"test. Probability values at $5 \%$ for different physicochemical parameters of Faisalabad, Nankana Shib and Kalar Kahar area. For moisture content $\mathrm{p}>0,0.05, \mathrm{p}>0.05$ for $\mathrm{pH}, \mathrm{p}>0.05$ for EC, $\mathrm{p}>0.05$ for free acidity, Lactone and total acidity, $\mathrm{p}>0.05$ for proline content and HMF content.

* The suggested values for proline content and electrical conductivity for new honey standards (Bogdanov et al., 1999)

** Council of the European Union. Council Directive 2001/110/EC of Dec. 20, 2001, relating to honey. Off. J. Eur. Commun., 2002, Jan 12, L10/47-L10/52

\section{pH}

The average $\mathrm{pH}$ from Lahore, Jhang and Kalar Kahar Apis dorsata honey samples were found to be 3.48 (3.44-3.73), 4.11 (3.57-4.62), 4.02 (3.52-4.74), respectively. These values showed no significant difference and fell within the prescribed range of $3.42-6.1$ [18]. The $\mathrm{pH}$ values obtained in present study showed close resemblance with the values (3.66 and 4.06) obtained by [17] in the honey samples of Apis dorsata harvested from two different nesting sites (trees) in Chitwan district, central Nepal. These $\mathrm{pH}$ values, however, lower as compares to the ones obtained by [12] in Apis dorsata honey samples harvested from four 4.68 (4.3-5.1), 4.58 (4.3-4.7), 4.39 (3.7-4.6) and 3.8 (3.7-4.3) Terai forests, Nepal.

\section{Electrical conductivity}

Average values of electrical conductivity (EC) of Apis dorsata honey were $249 \mu \mathrm{S} / \mathrm{cm}$ (233.0-272.67 $\mu \mathrm{S} / \mathrm{cm})$, $911.53 \mu \mathrm{S} / \mathrm{cm}$ $(277.67-1347 \mu \mathrm{S} / \mathrm{cm})$ and $459.97 \mu \mathrm{S} / \mathrm{cm}$ 
(258.67-524.33 $\mu \mathrm{S} / \mathrm{cm}$ ), from Lahore, Jhang and Kalar Kahar. All these values of electrical conductivity value of were higher than least limits of international honey standards and of directive 2001/110/EC from council of European Union for blossom honey $(\sim 0.8 \mathrm{mS} / \mathrm{cm})$. [17] recorded EC values of Apis dorsata honey as 0.9 $\mathrm{mS} / \mathrm{cm}$. The conductivity values found by [12] were $0.060(0.44-0.70), 0.61$ (0.51$0.74), \quad 0.48 \quad(0.19-0.54)$ and $0.22 \mathrm{mS} / \mathrm{cm}$ (0.18-0.42). EC value $0.558 \mathrm{mS} / \mathrm{cm}$ was reported by [4]. All these EC values were lower than the value found in Apis dorsata honey samples from Punjab.

\section{Free acidity}

The Free acidity in Apis dorsata honey from Lahore, Jhang and Kalar Kahar were $25.77 \mathrm{meq} / \mathrm{kg} \quad(19.00-33.33 \quad \mathrm{meq} / \mathrm{kg})$, $42.65 \mathrm{meq} / \mathrm{kg} \quad(21.67-58.00 \mathrm{meq} / \mathrm{kg})$ and $37.11 \mathrm{meq} / \mathrm{kg} \quad(26.83-58.17 \mathrm{meq} / \mathrm{kg})$, respectively. Although average free acidity was found less than $50 \mathrm{meq} / \mathrm{kg}$, a maximum limit for acidity prescribed by international honey standards and by the directive 2001/110/EC from the Council of European Union. However, few (samples no 11, 13 and 16) from Jhang and samples no 7and 8 from Kalar Kahar had free acidity value above the permissible limit. [19] from Pakistan, [20] from Calcutta, India reported formic acid value in Apis dorsata honey. [17] did not report free or total acidity in Apis dorsata honey samples collected from Chitwan district, Central Nepal. [12] reported free acidity values $44.459 \mathrm{meq} / \mathrm{kg}$ (26.5-51.59meq/kg), $43.169 \mathrm{meq} / \mathrm{kg} \quad(35.00-$ $47.519 \mathrm{meq} / \mathrm{kg}), \quad 43.149 \mathrm{meq} / \mathrm{kg} \quad(33.5-$ $60.009 \mathrm{meq} / \mathrm{kg})$ and $48.9 \mathrm{meq} / \mathrm{kg} \quad(39.5-$ 61.00) of Nepal's Apis dorsata honey. The free acidity values obtained from present study are closer to the values of Apis dorsata honey reported by [12].

\section{Lactone content}

Lactone content was measured at an average of $33.44 \mathrm{meq} / \mathrm{kg}(30-32.83 \mathrm{meq} / \mathrm{kg})$ of honey sample collected from Lahore, $15.53 \mathrm{meq} / \mathrm{kg} \quad(4.00-34.16 \mathrm{meq} / \mathrm{kg})$ from Jhang and $12.77 \mathrm{meq} / \mathrm{kg}(6.00-21.67 \mathrm{meq} / \mathrm{kg})$ from Kalar Kahar. All these values of lactone content of Apis dorsata honey were found L.A vales closer to the values were $13.2 \mathrm{meq} / \mathrm{kg}(0.00-20.5 \mathrm{meq} / \mathrm{kg}), \quad 18.79$ $\mathrm{meq} / \mathrm{kg}(11.5-18.00 \mathrm{meq} / \mathrm{kg}), 15.14 \mathrm{meq} / \mathrm{kg}$ $(12.5-18.5 \mathrm{meq} / \mathrm{kg})$ and $3.5 \mathrm{meq} / \mathrm{kg}(7.00-$ $21.00 \mathrm{meq} / \mathrm{kg}$ ) determined by [12]. [4] noticed the lactone value in Spanish honey at an average of $5.08 \mathrm{meq} / \mathrm{kg}$.

\section{Total acidity}

The total acidity calculated for honey samples of Lahore $60.21 \mathrm{meq} / \mathrm{kg}$ (51.20$69.67 \mathrm{meq} / \mathrm{kg}$ ), Jhang $55.46 \mathrm{meq} / \mathrm{kg}$ (51.20$82.47 \mathrm{meq} / \mathrm{kg}$ ), and Kalar Kahar was $50.36 \mathrm{meq} / \mathrm{kg} \quad(31.67-74.83 \mathrm{meq} / \mathrm{kg})$. [12] reported total acidity value of $61.74 \mathrm{meq} / \mathrm{kg}$ $(30.00-71.50 \mathrm{meq} / \mathrm{kg}), \quad 67.98 \mathrm{meq} / \mathrm{kg} \quad(46.5-$ $64.00 \mathrm{meq} / \mathrm{kg}), \quad 60.02 \mathrm{meq} / \mathrm{kg} \quad(46.00-$ $77.00 \mathrm{meq} / \mathrm{kg})$ and $56.39 \mathrm{meq} / \mathrm{kg} \quad(53.00-$ $79.50 \mathrm{meq} / \mathrm{kg}$ ) in Apis dorsata honey collected from four Teari forest, Nepal. [16] from Philippines reported total acidity value of $40.2 \mathrm{meq} / \mathrm{kg}$ as an average in Apis dorsata honey. [4] reported $33.23 \mathrm{meq} / \mathrm{kg}$ mean total acidity in honey samples from Central Spain. High acidity has been considered as an indicator of purity of honey by [21]. Possible reason of elevated acidity values in Apis dorsata honey is unlike that of $A$. mellifera honey is because of its multi-floral foraging behavior. Different types of nectars with various concentrations of acids may ultimately result into high level of acidity. These high acidity values of Apis dorsata honey could be due to limited or short termed shelf life.

\section{Proline content}

Proline content were estimated at an average of $5146.62 \mathrm{mg} / \mathrm{kg}(4465.13-8760.51 \mathrm{mg} / \mathrm{kg})$ from Lahore, $4328.44 \mathrm{mg} / \mathrm{kg} \quad$ (3415.73$6344.61 \mathrm{mg} / \mathrm{kg}$ ) Jhang and $3554.68 \mathrm{mg} / \mathrm{kg}$ $(2808.38-7939.09 \mathrm{mg} / \mathrm{kg})$ of Apis dorsata honey samples from Kalar Kahar. [12] 
reported $98.38 \mathrm{mg} / \mathrm{kg} \quad(23.38-153.6 \mathrm{mg} / \mathrm{kg})$, $100.8 \mathrm{mg} / \mathrm{kg} \quad(20.65-330.00 \mathrm{mg} / \mathrm{kg})$, $119.98 \mathrm{mg} / \mathrm{kg} \quad(42.15-193.18 \mathrm{mg} / \mathrm{kg}) \quad$ and $160 \mathrm{mg} / \mathrm{kg}(101.97-198.81 \mathrm{mg} / \mathrm{kg})$ of proline content of $A$. dorsata honey samples from Nepal. [17] reported 875.82ppm of proline content in A. dorsata honey samples from Nepal. [22] reported $76.0 \mathrm{mg} / 100 \mathrm{~g}$ and $81.1 \mathrm{mg} / 100 \mathrm{~g}$ proline in honey samples from two different geographical regions of Spain. The proline content of A. dorsata honey samples from Punjab (Lahore, Jhang and Kalar Kahar) was higher from all of them. These results show no resemblance with previous determination of proline content in Apis dorsata honey samples. However, proline content of Jhang and Kalar Kahar were close. [23] determined proline content varied from 437.82 to $2169 \mathrm{mg} / \mathrm{kg}$ in A.mellifera honey. Some authors have reported that high values for proline are typical for honeydew honeys [24]. The proline content has been shown to vary considerably between different honeys [10]. [25] Louveaux (1985) believe that the majority of the proline comes from bee salivary secretion.

\section{HMF Content}

HMF is one of the important quality criterions to determine the freshness and overheating of honey. In order to check the freshness of Pakistani Apis dorsata honey average HMF Content were measured as $36.41 \mathrm{mg} / \mathrm{kg} \quad(28.54-43.13 \mathrm{mg} / \mathrm{kg}) \quad$ from Lahore, $\quad 30.74 \mathrm{mg} / \mathrm{kg} \quad(16.32-53.76 \mathrm{mg} / \mathrm{kg})$ Jhang and $89.93 \mathrm{mg} / \mathrm{kg}(48.45-149.76 \mathrm{mg} / \mathrm{kg})$ from Kalar Kahar. HMF Content reported by [12] was $33.36 \mathrm{mg} / \mathrm{kg}(7.68-61.28 \mathrm{mg} / \mathrm{kg})$, $30.36 \mathrm{mg} / \mathrm{kg}(3.84-57.60 \mathrm{mg} / \mathrm{kg}), 36.48 \mathrm{mg} / \mathrm{kg}$ $(7.68-59.52 \mathrm{mg} / \mathrm{kg})$ and $56.10 \mathrm{mg} / \mathrm{kg}(21.12-$ $76.6 \mathrm{mg} / \mathrm{kg}$ ) from four Terai forests, Nepal. The present study showed that HMF content in Lahore and Jhang honey samples were within the limit of International honey Standards i-e $40 \mathrm{mg} / \mathrm{kg}$, but the HMF content of Apis dorsata honey samples collected from Kalar Kahar exceeds the maximum limit described for HMF Content by Codex Altimenterus. The reason of high HMF content might be that, all the three areas from where these honey samples were collected, have sub-tropical climate and according to [26] the honey produced in subtropical climate have high HMF value which may exceeds $40 \mathrm{mg} / \mathrm{kg}$.

\section{Conclusions}

The present investigations conclude that honey produce by Apis dorsata showed various quality parameters close to the International honey standards. Moisture content is beyond the Standard limits and seems to be specific in the honey produced by this honeybee species.

\section{Authors' contributions}

Conceived, designed the experiments: S Qamer, Performed the experiments: R Kousar, Analyzed the data: R Kousar, Wrote the paper: S Qamer.

\section{References}

1. Ruttner F (1988). Biogeography and taxonomy of honey bees, Springer-Verlag, Berlin Heidelberg 284.

2. Wongsiri S, Thapa R, Oldroyd B \& Burgett MD (1996). A magic bee tree: Home of Apis dorsata. Am Bee J 136: 196-199.

3. Thapa R, Wongsiri S \& Prawn S (1999b). Colony migration of Apis dorsata in the northern parts of Thailand. Asian bees and bee keeping in: proceedings of Res and Dev 39-43.

4. Iglesias MT, De lorenzo C, Polo MDC, Martin-alvarez PJ \& Pueyo E (2004). Usefulness of amino acid composition to discriminate between honeydew and floral honeys. Application to honeys from a small geographic area. J Agric Fd Chem 52: 84-8.

5. Qamer S, Muzaffar N, Ali SS \& Shakoori AR (2005). Physicochemical analysis of Pakistani unifloral honey from different nectar sources. Proc Pakistan Congr Zoo 25: 123-130.

6. Khan KA, Al-Ghamdi AA \& Ansari MJ (2016). The characterization of blossom honeys from two provinces of Pakistan. 
Italian Journal of Food Science 28: 625637.

7. Iftakhar F, Mahmood R, Islam N, Sarwar G, Masood MA \& Shafiq H (2014). Physicochemical Analysis of Honey Samples Collected from Local Markets of Rawalpindi and Islamabad, Pakistan. American Journal of Biochemistry 4 (2): 35-40.

8. Abu-tarboush HM, Al-kahtani HA \& Elsarrage MS (1993). Floral type identification and qulity evaluation of some honey types. Fd Chem 46:13-17.

9. Bonod L, Sandoz JC, Loublier Y \& Phamdelegue MH (2003). Learning and discrimination of honey odours by the honey bees. Apidologie 34: 147-159.

10. Bogdanov S, Lullmann C, Martin P, Ohe Von Der W, Russmann H, Vorwohl G, Marcazzan GL, Piro R, Flamini C, Morlot M, Lehritier J, Borneck R, Marioleas P, Tsigouri A, Kerkuliet J, Ortiz A, Ivanov T, Darcy B, Mossel B \& Vit P (1999). Honey quality and international regulatory standards: review by the International Honey Commission. Bee Wld 80: 61-69.

11. Steel RGD \& Torrie JH (1981). Analysis of variance factorial experiments. In: Principal and procedure of statistics. $2^{\text {nd }}$ Ed MeGraw Hill International Book Company Tokyo, pp. 336-375.

12. Qamer S, Ahmad F, Latif F, Ali SS \& Shakoori AR (2008). Physicochemical Analysis of Apis dorsata honey from Terai forests, Nepal. Pakistan Journal of Zoology 40: 53-58.

13. Phadke RP (1968). Studies on Indian honey. Proximate composition and physicochemical characterization of honey from wild honey bee Apis dorsata, Apis florea and Trigona. Indian Bee J 30: 3-8.

14. Malkar A (1997). Comparative pollen and chemical analysis of West Bengal honey. Ph.D. thesis, University Calcutta, India.

15. Laude VT, Naegel L \& Horn H (1991).The physicochemical properties of some Philippine honey. Apidologie 22: 371-257.
16. Minah HV, Mendoza BG \& Laigo FM (1971). The chemical composition of honey produced by Apis dorsata. J Apic Res 10: 91-97.

17. Joshi SR, Pechhaker H, Willam A \& Vonderohe W (2000). Physicochemical characteristic of Apis dorsata, Apis cerana and Apis mellifera From Chitwan district, Nepal. Apidologie 31: 367-375.

18. White JRJW, Riethof ML, Subers MH \& Kushnir I (1962).Composition of American honey. Tech Bull U. S. Dept Agric 126: 144.

19. Latif A, Qayyum A \& Mazoor-ul-haq (1956). Research on the composition of Pakistan honey. Pakistan. J scient Res 8: 163-380.

20. Mitra SN \& Mathew TV (1968). Studies on the characterizations of honey. J Proc Inst Chem India 40: 26-30.

21. Suarez-luque S, Mato I \& Huidobro JF (2002). Rapid determination of minority organic acids in honey by high performance liquid chromatography. $J$ Chromatogr 955: 207-214.

22. Sanchez MDP, Huidobro JF, Matp I, MuniateguI S \& Sancho MT (2001). Correlation between Proline content of honey and botanical origin. Deutsche. Lebensum. Rundschau 5: 171-175.

23. Meda ACE, Lamien JMM, Romito OG \& Nacoulma (2005). Physicochemical analysis of Burkana Fasan honey. Acta Vet Brno 74: 147-152.

24. Diez MJ, Andres C \& Terrab A (2004). Physicochemical parameters and pollen analysis of Moroccan honeydew honeys. International Journal of Food Science and Technology 39: 167-176.

25. Louveaux J (1985). Le miel Cah. Nutr Diet 20: 57-70.

26. Lagrange V \& Sanders SW (1988). Honey in cearal-based new food products. Cereal Fd Wld 33:833-838. 